\title{
Die Sendingpraktyk van die Ned Geref Kerk: Enkele ten- dense vanaf 1952 tot met die eeuwenteling
}

\author{
G van der Watt ${ }^{1}$ \\ (Universiteit van die Vrystaat)
}

\section{ABSTRACT \\ Practical mission of the dutch reformed church: Some tendencies since 1952}

In this past half century the Dutch Reformed Church was continuously building on the tradition of extended missionary involvement within South Africa as well as in several countries in Southern Africa. During the fifties and sixties there were a flourishing of activities, driven by, amongst other reasons, an idealism and optimism concerning the homeland-policy or grand apartheid. The seventies and eighties were therefore characterised by resistance; the DRC had to reconsider its approach. While the church had to largely withdraw from the traditional fields, it found alternative areas for involvement, mainly abroad. In the nineties a whole new world dawned and the church once again had to adapt. The emphasis shifted to local congregations and a variety of approaches. World mission came into the focus. The way ahead for the Dutch Reformed Family of Churches could only be as one united church, fulfilling it's calling to mission within the African and especially South African context, while staying true to its reformed tradition.

\section{INLEIDING}

In ' $\mathrm{n}$ feesgeskrif, Die Blye Boodskap Deur Drie Eeue in Suid-Afrika, bied G B A Gerdener ' $n$ kort oorsig oor die totale sendingterrein in Suid Afrika en bevind dan: "Die mees uitgebreide sendingwerk van nasionale karakter is dié van die Nederduitse Gereformeerde Kerk" (1952:28). Hierdie betrokkenheid strek egter ook oor die landsgrense, tot in haas elke land in Suider Afrika. Die voortsetting en uitbouing van dié historiese erfenis van omvattende sendingbetrokkenheid bly een van die uitstaande kenmerke van die Ned Geref Kerk - ook deur die afgelope vyftig jaar.

Die jaar 1952 het geen spesifieke sendinghistoriese betekenis nie, maar by die viering van 350 Jaar Gereformeerd is dit goed om die sendingaktiwiteite en enkele tendense van die laaste vyftig jaar vlugtig in oënskou te neem. Daar het inderdaad veel gebeur, te veel om selfs net

1 Dr Van der Watt is predikant met opdrag sending in diens van die Vrystaatse- en Algemene Sinode van die Ned Geref Kerk: Posbus 1399, Bloemfontein, 9300, sending@,ngkerkovs.co.za 
oorsigtelik hier aan die orde te stel. Sendingaktiwiteite en benaderings in hierdie tydperk hang ten nouste saam met gebeure op maatskaplike en politieke terrein en die selfverstaan van die kerk en haar roeping. ' $n$ Totale verskuiwing in benadering het merkbaar geword oor die afgelope vyftig jaar. Ook hierdie fase in die sendinggeskiedenis van die Ned Geref Kerk bly, in die woorde van Bavinck (1954:274), die verhaal van "de grote daden van de opgestane Jezus Christus, die zijn onwillige, tegenstrevende Kerk haars ondanks meeneemt op zijn zegetocht door de wereld..."

Die periode kan losweg in die volgende drie tydperke verdeel word: sendingopbloei en -idealisme in die vyf- en sestigerjare, gesamentlike sending en afplatting in die dekades van sewentig- en tagtigerjare en die jongste tydperk, sedert die jare negentig, van gemeente-inisiatiewe en wêreldsending.

\section{SENDINGOPBLOEI EN -IDEALISME IN DIE VYF- EN SES- TIGERJARE}

\subsection{Historiese betrokkenheid en benadering}

Die Ned Geref Kerk het ' $n$ lang geskiedenis van wye sendingbetrokkenheid. Uit die binnelandse sending (Crafford 1982), het die Ned Geref Sendingkerk in 1881 (Kriel 1961) en die Ned Geref Sendingkerk van die Vrystaat in 1910 en van Transvaal in 1932 ontstaan - dié van Natal en die Kaap sou later eers amptelik konstitueer. In die buiteland (Cronje 1981) het die Kaapse Kerk ' $n$ jarelange, omvattende werksaamheid gehad: sedert 1877 in Botswana, vanaf 1889 in Malawi, in Zimbabwe vanaf 1891, saam met die Sudan United Mission in Nigerië sedert 1908 en in dieselfde jaar het die deure ook die eerste keer in Mosambiek oopgegaan. Die Vrystaatse Kerk het in 1899 in Zambië begin werk. Die Transvaalse Kerk het die werk in Kenia in 1944 begin ondersteun en in die jaar daarna begin met werk in Swaziland. Lewenskragtige "dogterkerke", met "n merkwaardige infrastruktuur van geboue, teologiese en ander opleidingsinrigtings, hospitale, skole, inrigtings vir gestremdes en goed opgeleide, inheemse leraars en ander personeel, het tot stand gekom. ' $n$ Groot sendingkorps van manne en vroue uit die Ned Geref Kerk het op al dié sendingvelde reusebydraes gelewer en selfs groot offers gebring.

Kenmerkend van die lang sendinggeskiedenis van die Ned Geref Kerk was gehoorsaamheid aan die Bybelse opdrag tot sending in Matteus 28:19 en Markus 16:15 (Robinson \& Botha 1986), maar veral ook die oortuiging dat die "Blankes" aan die "Suidhoek van Donker Afrika" geplant is, met die doel om die evangelie na die "heidense nasies... van hierdie vasteland" uit te dra. Die Sendingbeleid van die Gefedereerde 
Ned Geref Kerke (Gerdener 1951, Crafford 1982:472, Lombard 1985: 178, Van der Watt 1990:86ev) van 1947 stel die doel van sending duidelik: "die insameling van siele vir God's Koninkryk" as eerste stap. Daarna volg "die stigting van gemeentes, en uiteindelik, van georganiseerde Kerke" Hierdie kerke moes onder voogdyskap van die moederkerk gelei word tot selfstandige (dws selfonderhoudende en selfregerende kerke). Inheemswording bly die ideaal, en "die tradisionele vrees vir gelykstelling tussen swart en wit ...gebore uit die afkeer van die idee van rasvermenging" " $\mathrm{n}$ realiteit. Daarom moes daar afsonderlike kerke vir die verskillende bevolkingsgroepe wees. Die kerk was dus gekant teen "sosiale gelykstelling" tussen swart en wit en dit het "sosiale differensiasie en geestes of kulturele segregasie" voorgestaan (Lombard 1985:321). "Hulpmiddels" soos opvoeding en onderwys, mediese en ander dienste was geoorloof, ook ter wille van die maatskaplike en ekonomiese opheffing tot selfrespekterende christen volke. Die sendingbeleid was dus in wese " $n$ rassebeleid; trouens sending is volledig in rasseterme verstaan as die beweging van die blanke kerk na "nie-blankes", selfs ook as die beweging na "nie blanke" kerke.

\subsection{Sendingoplewing}

Sedert die vyftigerjare, meer spesifiek 1955, was daar 'n merkbare sendingoplewing in die Ned Geref Kerk, met veel vrug op die wydvertakte arbeid. Die historiese werk op die buitelandse velde is op geordende wyse voortgesit en konstant uitgebou. Die grootste oplewing was egter in die binneland: die swart gebiede van Transvaal (veral die Laeveld), die Transkei en Ciskei, Noord Kaapland (Phororo) en die Goudvelde (Mynkampongs). Werk onder die Indiërbevolking het in alle erns begin. Die klem was egter op plaaslike werk, die Jerusalem en Judea: "The DRC Mother Churches in the various provinces look upon local mission as their first duty. In most towns and villages such work has been initiated, at first in co-operation with the European congregation and gradually passing on towards self-help and self-determination" (Gerdener 1958:32)

Die sendingoplewing het nuwe eise aan sendingbeplanning gestel; ' $\mathrm{n}$ ad hoc kommissie van die Federale Sendingraad het die werk help koördineer en eweredig onder sinodes versprei. Die kleiner sinodes soos Natal en Suid-Wes Afrika moes gehelp word. Sinodale Sendingkommissies en die onderskeie sendingsekretarisse het 'n groot rol gespeel. Provinsiale sendingblaaie, maar veral $O p$ die Horison en later Die Sendingblad, het met besielende berigte die oplewing aangevuur. Met entoesiasme is die werk deur die Vrouesendingbondtakke ondersteun (vg1 berigte in elke uitgawe van Die Sendingblad). 
Die lidmaattal in die binnelandse jongkerke het spoedig verdubbel en die van die moederkerk ingehaal (Lombard 1985:178), terwyl die aantal sendelinge dramaties toegeneem het. Die stigting van nuwe kerke, byvoorbeeld die Ned Geref Bantoekerk (Transkei, Ciskei, Phororo) in 1951, die Ned Geref Sendingkerk van Natal in 1952 en die aanvang van werk onder die Indiërbevolking, het verdere entoesiasme gewek. Die volgende redes (Van der Watt, 1987:228ev) vir die sendingopbloei van die vyftigerjare word genoem:

- Verskillende belangrike kongresse, soos die Kerklike Kongres oor Rasse-aangeleenthede in 1950 en 'n aantal opvolgkonferensies.

- In 1955 het die Tomlinson-verslag oor Tuislandontwikkeling verskyn. Daarin word die kerk opgeroep om 'n groter rol te speel in die daarstel van ' $n$ geestelike en religieuse basis vir sosio-ekonomiese en politieke ontwikkeling in veral die swart tuislande (Crafford 1982:224). Dit is opgevolg met ' $n$ Volkskongres deur Sabra in 1956, waartydens die Ned Geref Kerk opgeroep is om die agterstand ten opsigte van sending onder swartes uit te wis.

- In die 1953 Bantoe-onderwyswet is bepaal dat die staat voortaan kerkskole sou oorneem. Dit het ruimte gelaat vir die kerk om tot groter mate op kerkplanting te konsentreer, veral ook nadat die $8 \mathrm{~km}$ radius beperking op die vestiging van nuwe sendingstasies of kerkpersele laat vaar is.

- Benewens die groeiende getal studente uit Stellenbosh en Wellington wat hulle vir die sending aangemeld het, het die totstandkoming van die Teologiese Fakulteit van Pretoria, met ' $n$ nuwe sendingdepartement onder professor H D A du Toit, dié getalle versterk: -van $10 \%$ het die getal afgestudeerdes wat na die sendingveld gegaan het skielik na $30 \%$ gestyg.

- Inspirerende besoeke van buitelandse sendingfigure soos Oswald Smith van Kanada en J H Bavinck van Nederland.

\subsection{Van sending na kerk}

Die sendingoplewing van die vyftigerjare word tot nuwe hoogtepunte in die sestigerjare gevoer. In die tydperk is die jongkerke as selfstandige kerkverbande gekonstitueer. Werksaamhede en eiendom van die sending word amptelik aan die jongkerke oorgedra. Die "vrug" van die sending het nou ryp begin word. Die hele proses val saam met die onafhanklikwording van verskeie voormalige kolonies. Die jongkerke het verantwoordelikheid begin neem en moes hulself posisioneer ten opsigte van die nuwe regerings. Hierdie dekade verteenwoordig die oorgang van sending na kerk. 
Tog onttrek die "moederkerk" nie uit die veld nie. Selfs ook nie die eerste tekens van opstand (Sharpeville 1961) en kritiek vanuit die ekumene teen die Ned Geref Kerk se benadering, byvoorbeeld die Cottesloe beraad (1960) en rimpelinge daarna, kon die groeiende sendingmomentum stuit nie; nuwe uitdagings is aangepak. Na ' $\mathrm{n}$ uitgebreide besoek aan die buitelandse sendingvelde berig Prof W J van der Merwe in Die Sendingblad (Mei 1965:10) dat daar tekens van groot herlewing en " $n$ ontvanklikheid vir die evangelie is. Die "afrigting van inheemse werkkragte" is nou die dringendste taak. Die "dogterkerke" moes "n leierskapsrol oorneem in post-koloniale Afrika.

Ook binnelands is met groot ywer voortgewerk. In 1967 was daar byvoorbeeld reeds 161 "inheemse" leraars en " $n$ groot aantal evangeliste in die Ned Geref Kerk in Afrika (NGKA) werksaam, maar ook steeds 125 sendelinge uit die Ned Geref Kerk. In Die Sendingblad (Des 1969: $403 \mathrm{ev)}$ bied die redakteur ' $\mathrm{n}$ oorsig oor die merkwaardig omvangryke sendingbetrokkenheid van die "Moederkerk" by die "Dogterkerke" in die dekade van sestig:

- Verskeie nuwe velde is in die tydperk betrek, soos die Transkei, Ciskei en Noord Kaap (werk het vervierdubbel). Talle nuwe sendingstasies, -hospitale en -skole is in die Transvaalse Laeveld en Swart gebiede gevestig. Die Vrystaatse kerk het in alle erns met werk in die Goudvelde, Lesotho (1957) en die Oos-Caprivi begin. In Kaokoveld, Okavango en die Boesmangebiede in Suid-Wes Afrika het die werk sedert 1955 momentum gekry en deure het weer begin oopgaan in Mosambiek (1966).

- Nog Indiërgemeentes is gestig; werk onder Moslems en Hindoes is in alle erns aangepak.

- Binnelands het werkkragte verdubbel en sendingbydraes tot drie keer meer as in die verlede. Die Ned Geref Sendingkerk het in die tydperk 67 nuwe gemeentes bygekry en met meer as een derde in lidmaattal gegroei. Teenoor ongeveer 1000 sendingpersoneel uit die Ned Geref Kerk, was daar reeds 10000 inheemse werkkragte in die dogterkerke.

- Daar was meer as 3000 sendingskole waarin ongeveer 220000 kinders onderrig ontvang het. Daar was 38 sendinghospitale, met meer as 8000 hospitaalbeddens, 7 skole vir blindes, 6 vir dowes, 3 vir serebraalgestremdes, 1 vir kleurlingepileptici, 7 inrigtings vir bejaardes, 1 vir ongehude Kleurlingmoeders, 12 kinderhuise en 10 bewaarskole.

- Die Ned Geref Kerk was verantwoordelik vir die instandhouding van 8 teologiese skole: 1 vir die Ned Geref Sendingkerk in Bellville, 
die 4 Stofberg skole (Pietersburg, Dingaanstat, Decoligny en Witsieshoek), 3 in die buiteland (Mkoma, Morgenster en Madzimoyo) Die benadering ten opsigte van teologiese opleiding is deeglik uitgeklaar (Die Sendingblad Desember 1965:25). Die Vrouesendingbond het die Minni Hofmeyr Skool vir maatskaplke werkers op Worcester en een vir swart werkers op Pietersburg help instandhou, asook die Friedenheim Sendinginstituut vir Dames op Wellington.

- Ook op literatuurgebied is veel gedoen. In 1957 is die Christelike Literatuurfonds gestig met die oog op insameling van fondse vir literatuurverspreiding. Die Ned Geref Sendingpers en die Ned Geref Sendinguitgewers het daaruit tot stand gekom, asook 'n reeks boekwinkels. Benewens talle boeke en traktaatjies in verskillende Afrikatale, is die Kinderbybel van John Murray in 4 tale vertaal, ' $n$ kategeseboek is opgestel en in 5 tale uitgegee, verskeie gesangeboeke in verskillende tale is versprei en Mema is gestig om moderne evangelisasiemiddele vir Afrika te ontwikkel.

- Deur die geskiedenis was sendelinge uit die Ned Geref Kerk grootliks verantwoordelik vir die vertaling van drie Bybels, in Sjona, Chichewa en Tiv. Daar is bekwaam voortgewerk aan hervertalings, ook in ander tale. Die Ned Geref Sendindrukkers het die volledige Bybel in Sotho gedruk.

' $\mathrm{n}$ Besondere kenmerk van sending in hierdie tydperk was die klem op missionêre diakonaat, byvoorbeeld die reusewerk deur Mfesani en Kerklike Aksie Noodhulp (KAN). Veel is op die terrein van mediese sending gedoen. Dawid Bosch (Die Sendingblad, April 1966:31) het dit help uitmaak dat hierdie werk nie meer bloot as "hulpdiens" verstaan kan word nie, maar as wesenlik deel van die sending: die taak van die kerk is Woordgetuienis (marturia), gemeenskap (koinonia) en diens (diakonia) In hierdie tydperk het nuwe, rigtinggewende publikasies oor die sending verskyn: die van Du Toit (1967), Crafford (1966), maar veral ook as opdragwerk van die ASSK die sendinghandboek van Van der Merwe (1967).

\subsection{Reglementering en strukturering van die sending}

Nadat die Algemene Sinode van Ned Geref Kerk in 1962 konstitueer het, kom die Kommissie vir Sending van die Algemene Sinode (later die Algemene Sinodale Sendingkommissie of ASSK) op 18 Oktober 1962 in die plek van die ou Federale Sendingraad. Ds Dawid Snyman word as eerste voorsitter verkies en ds P E S Smith as eerste voltydse sendingsekretaris beroep (1965).

Die ASSK het as opdrag: advies aan die Algemene Sinode, koördinering, navorsing en beplanning, voorligting, inligting en Die Sending- 
blad as gesamentlike blad (Die Sendingblad April 1965:5). Werksaamhede soos die teologiese skole, die CLF en sendingwerk onder Indiërs was ook die ASSK se verantwoordelikheid. Die werksterreine van die onderskeie Sinodale Sendingkommissies was eweredig verdeel en netjies afgebaken. Alles is gereglementeer. Sinodale sendingkantore (sendingsekretarisse) het ' $n$ belangrike rol gespeel.

Dit is opvallend hoe ' $\mathrm{n}$ groot gemeentebetrokkenheid daar by die sending in hierdie era was, veral by plaaslike sending. Elke uitgawe van Die Sendingblad was vol berigte oor gemeentes en lidmate (en studente!) se inisiatiewe - ' $n$ geesdriftige skare van mense was betrokke. Opvallend is ook reusebydrae van vroue binne die strukture van die Vrouesendingbond: die pos van menige sendeling of sendingwerk(st)er, die oprigting van talle geboue en die instandhouding van inrigtings is deur dié ondersteuning moontlik gemaak (Cronje 1984). Tog is oor die sending hoofsaaklik nog as sinodale werksaamheid gedink; gemeentes is daarin bloot ondersteunend. Op kritiek as sou dit op ' $\mathrm{n}$ kollegialistiese benadering dui, skryf Van der Merwe (1967:104): die beste belang van die koninkryk word gedien "indien gemeentes in hul breëre kerkverband saamwerk en die Sinodale Sendingkommissies kan dit bevorder".

Een van die eerste opdragte aan die ASSK was om die sendingbeleid te herskryf. In 1966 is die "Algemene Sendingreglement" voltooi. As kerkordelike reglement het dit tog merkbaar verskil van die ou sendingbeleid. Die uitgangspunt was nie meer die "blanke" volksplanting nie, maar is baseer op die Heidelbergse Kategismus, Sondag 21, se leerstuk oor die heilige algemene Christelike kerk: "Sending is die handeling van die drie-enige God, Vader, Seun en Heilige Gees, met die wêreld, waardeur Hy uit die ganse menslike geslag vir Hom 'n gemeente deur sy Woord en Gees vergader, deur wie Hy sy Woord aan die gevalle wereld laat verkondig, die gemeenskap van heiliges uit alle nasies en volke tot stand bring en diens aan die wêreld in nood laat lewer vir die uitbreiding van Gods koninkryk tot die voleinding". Die doel bly egter die tot stand bringing van "afsonderlike selfstandige kerke uit verskillende bevolkingsgroepe". Die verhouding tussen moeder en dogterkerk is volledig gereglementeer.

Die verskillende sending- of "bantoekerke" kom in 1963 byeen as die Algemene Sinode van die Ned Geref Kerk in Afrika (NGKA). Die Indian Reformed Church (later Reformed Church in Africa) is in 1968 gestig aan die hand van ' $n$ reglement wat die ASSK daarvoor opgestel het. Deurgaans word nog verkies om die terme "moeder-" en "dogterkerk" te gebruik as uitdrukking van die "intieme band". "n Belangrike vraag was na die kerkordelike verband tusen "moeder-" en "dogterkerke". Aktes van Ooreenkomste is opgerig, waarin die nuwe "vennoot- 
skap" nog deur reste van die ou "voogdyskap" ontsier word (Jonker 1962, Van der Merwe 1985:88). Die Federale Raad van Ned Geref Kerke is in 1964 gekonstitueer. Waarom daar deurgaans voorkeur gegee word aan " $\mathrm{n}$ federatiewe verband om uitdrukking te gee aan die eenheidsband tussen al die kerke wat uit die sending van die Ned Geref Kerk tot stand gekom het, verduidelik Prof W J van der Merwe in sy openingsrede by die 1968 sitting van die Raad (Die Sendingblad, Des 1968:403): dit gaan om verskeidenheid binne die eenheid.

\subsection{Idealisme}

In 1967 is daar ' $n$ belangrike nasionale sendingkongres op Beaufort Wes gehou. Daar is opgewonde besin oor die huidige sendingsituasie en nuwe uitdagings. Strategië is beplan. In die dekades van vyftig en sestig is die Ned Geref Kerk se sendingaktiwiteit tot 'n hoogtepunt gevoer. Dit was besiel met ' $n$ idealisme, waarin die verwantskap met die republikeinse ideaal meermale aan te toon is: selfrespekterende, ontwikkelde tuislande vir die onderskeie bevolkingsgroepe en ordelike afsonderlikheid (apartheid) moes en kon verwesenlik word! Die era is gekenmerk deur die "Aksent op die Bantoetuislande" skryf E C D Bruwer in Die Sendingblad (Des 1967:5). Daar was "n optimisme. Die inheemswording van kerk en staat sou ' $n$ gunstige atmosfeer skep waarbinne die Woord rustig sy gang kon gaan, skryf ds J A Greyling (Die Sendingblad, Mei 1966:4). So sou die sending ook ' $\mathrm{n}$ bolwerk teen die opkomende kommunisme vorm. Hierdie ideale sou egter wreed ontnugter word in die twee opvolgende dekades.

\section{WEERSTAND EN POGINGS TOT GESAMENTLIKE SEN- DING IN DIE SEWENTIGER- EN TAGTIGERJARE}

\subsection{Weerstand teen die sending- en rassebeleid}

Sedert die laat sestigerjare was dit al duidelik dat die winde van veranderinge in Afrika begin waai het. In die sewentigerjare kry die Ned Geref Kerk se sending dié wind van voor. Die tydperk word gekenmerk deur groeiende politieke spanning en voortdurende onrus, veral sedert die Soweto onluste van 1976, die opkoms van die swart bewussynsbeweging, swart teologie en die kerklike ondersteuning van rewolusie en geweld - alles deel van die "totale aanslag" van die Kommunisme, het die slagkreet daarteen gelui. Vanuit die ekumene, maar veral ook uit die geledere van die jongkerke van die Ned Geref Kerk Familie, kom daar skerp weerstand teen die Ned Geref Kerk se beleid, by name teen die sendingbenadering. Dit word as dwaling en selfs kettery tipeer, vergelyk Ottowa 1982, die Ned Geref Sendingkerk se "status confessiones" en uiteindelik die Belhar Belydenis (1986). Die idealisme van die sestigerjare sou moes plek maak vir herbesinning, apologie en die uitwerk van 
' $\mathrm{n}$ nuwe rasse- en sendingbenadering. In die sewentiger- en tagtigerjare word die kerk se energie grootliks opgeneem in die formulering en verdediging van Ras Volk en Nasie (1974) en daarna Kerk en Samelewing (1986 en 1990). Ook oor die sending sou daar nuut gedink moes word; dit was noodsaaklik om ook eenheid, versoening en geregtigheid te verreken as wesenlike aspekte van die sendingopgaaf.

Dat daar uit die sending selfstandige kerke ontstaan het, beteken dat die era van "gesamentlike sending" nou aangebreek het. Wat dit alles sou behels, veral vir die verhouding tussen "moeder" en "dogter", wat intussen "susters" geword het, sou in hierdie dekades uitgewerk moes word. Daar is opnuut onsekerheid oor hoe sending gedefinieer behoort te word. Die rol en kerkregtelike posisie van die sendeling kom in die branding.

In hierdie tydperk is die werksaamhede van die vyftiger en sestigerjare voortgesit en hier en daar selfs verder uitgebou. Die werk is steeds hoofsaaklik vanuit die verskillende sinodale kantore onderneem en deur gemeentes ondersteun. Die Vrouesendingbond maak steeds ' $\mathrm{n}$ besondere bydrae om fondse vir projekte te vind. Besielende berigte verskyn in Die Sendingblad, daar word gereeld sendingkonferensies en kongresse gehou en die literatuur- en mediabediening word voortgesit. In 1971 word dr J M Cronje as tweede sendingsekretaris van die ASSK beroep.

Tog is daar ' $\mathrm{n}$ skielike en duidelike afplatting in sendingaktiwiteite. In Die Sendingblad (Maart 1971:93) verskyn daar, in 'n swart raampie, 'n kort noodberig en oproep tot gebed. Dit was tiperend van dié tyd. Ds Dawid Snyman skryf: "Dinge loop vinnig baie skeef in Zambië. Ek vrees ons sal binne afsienbare tyd miskien net ' $n$ paar sendelinge in diens daar hê. Die kanse om 'n visum of werkspermit vir nuwe sendelinge te kry, is haas onmoontlik. Die politieke spanning teen Suid-Afrika laai blykbaar volgens gegewens by die dag op. Ons stel die jong kerk daar plus die paar personeellede se lewe en arbeid in die hande van die Koning van die kerk". In 1977 verskyn daar 'n omvattende verslag in 'n reeks artikels in Die Sendingblad onder die titel: "Veranderinge en oorgang in die sending". En in 1978 besluit die Algemene Sinode: "Die sinode roep kerkrade en ringe op om met die oog op die faktore wat al groter weerstand teen die sending opbou en al moeiliker omstandighede waaronder sendingwerk gedoen word, die geloof en die entoesiasme vir die saak van die Koninkryk nie te verloor nie" (Notule ASSK 1978).

\subsection{Bestaande werksaamhede afgeskaal, alternatiewe velde gevind}

Hoewel die totale sendingbegroting jaarliks gegroei het, was daar minder direkte betrokkenheid. Groot tekorte op die sendingbegrotings het dus spoedig ontstaan. Sendingposte is afgeskaal, selfs groepe sendelinge is 
uit die veld teruggeroep. Een na die ander pos van sendingsekretaris is uitfasseer (Van Niekerk 1997). Die totale sendingpersoneel uit die Ned Geref Kerk het in die tydperk 1973 tot 1977 vanaf 1078 na 551 gedaal, terwyl sendingleraars uit die Ned Geref Kerk in dieselfde tydperk vanaf 308 na 192 gedaal het. In hierdie tydperk is die Vrouesendingbond en Kindersendingkrans na ' $n$ lang stryd ontbind.

Daar is in hierdie tydperk tog ook met ' $n$ aantal nuwe werksaamhede begin. Opvallend is egter dat die klem nou wegskuif van net ' $\mathrm{n}$ betrokkenheid by die jongkerke in die Ned Geref Kerk familie na nuwe velde, meestal in die buiteland.

In 1974 begin die Vrystaat met sendingwerk in Japan. In dieselfde jaar word daar begin met eilande sending. In 1978 kom vra ds Thurairajah hulp vir die kerk in Sri Lanka, wat opgevolg is met besoeke aan verskeie lande in die Ooste en betrokkenheid deur veral die Sinode van Wes Transvaal. (Daarmee is die historiese band tussen die Anglo Boere-oorlog en die sending weer onderstreep). In 1979 is daar begin met werk in Portugal, ook met die oog op die stryd teen kommunisme daar. In die vroeë tagtigerjare word begin met werk in Frankryk en later in België (Noord-Kaap Sinode). Al hoe meer berigte in Die Sendingblad handel nou oor werk in lande soos Indië, Taiwan, Hong Kong, ensovoorts. Die teenwoordigheid van die Suid Afrikaanse Weermagkapelane op die Grens skep nuwe moontlikhede vir sendingbetrokkenheid, veral onder die Boesmans.

Die "totale aanslag" van die kommunisme teen kerk en koninkryk moes die hoof gebied word. Dit het nuwe uitdagings aan en ' $\mathrm{n}$ motivering vir die sending gebied. Die ASSK besluit in 1972 om " $\mathrm{n}$ klein kommissie vir Sending onder die Kommunisme in die lewe te roep. Bepaalde werksaamhede sou vertroulik wees. Daar is begin met fondsinsameling en in 1974 is ds Pieter de Wet beroep as Sekretaris vir Sending onder die Kommunisme. Die werksaamhede het behels: Bybelverspreiding, veral in die hawens, ondersteuning aan projekte om Bybels in kommunistiese lande te versprei, voorligting aan veral swart en bruin mense oor die gevare van kommunisme, ondersteuning aan radio-uitsendings na kommunistiese lande en die publisering van berigte oor lydende Christene agter die ystergordyn. In 1978 het die ASSK die kommissie versoek om te kyk na "'n Omvattende Meesterplan en strategie vir die bekamping van Kommunisme in Suider Afrika" ... "en besondere aandag te gee aan meer effektiewe anti-kommunistiese propaganda onder die Swartbevolking” (ASSK Notule 1978).

\subsection{Oor die sending moes daar weer besin word}

Dat daar nuut oor die kerk se sendingbenadering besin sou moes word, was duidelik. Was dit die kerk se taak om te help met tuislandont- 
wikkeling? vra ds Eddie Bruwer in Die Sendinblad (Junie 1974:187). Daar moet gewaak word teen te noue identifikasie met politieke ideale. Meermale word daar in die tydperk ook besin oor wat gesamentlike sending alles behels. In 1978 besluit die Algemene Sinode: "die Sinode sien gesamentlike sending met die Jongkerke in die huidige sendingsituasie as die belangrikste sendingmetode" (ASSK Notule 1978). In gesamentlike sending was die posisie van die sendingleraar in die jongkerk ' $n$ belangrike kwessie. Onder wie se toesig sou hy staan? Mettertyd is uitgemaak dat hy lidmaat moes word en volledig onder toesig van die kerk waarbinne hy arbei moes staan (Smit 1974). Gesamentlike sending kon alleen slaag as daar die regte gesindheid van wedersydse respek en liefdevolle geloofsgemeenskap is. Al hoe meer handel die debat oor goeie gesindhede en wedersydse respek. In die bereidheid tot egte gemeenskap van gelowiges en sigbare liefde, lê die geloofwaardigheid van die Ned Geref Kerk se sending, skryf prof Willie Jonker (Die Sendingblad Mei 1978:150). Vir gesamentlike sending is goeie skakeling nodig, die regte beplanning, goeie begrip vir mekaar se eiesoortigheid, onderlinge respek en ' $\mathrm{n}$ "vennootskap in gehoorsaamheid" skryf prof Koos Smit in Die Sendingblad (Julie 1985:188). Om gesamentlike sending prakties te verduidelik, gee die ASSK in 1986 ' $\mathrm{n}$ handleiding uit: So stuur Ek julle (Erasmus \& Botha 1986).

In die sewentiger en tagtigerjare, die hoogbloei van die Billy Graham- en die Lausanne- beweging, kom die begrip evangelisasie ook sterk na vore. In 1975 was dit die Jaar van Sending en Evangelisasie, waaruit verskillende evangelisasie-aksies gebore is. Sending en evangelisasie is as twee verskillende konsepte hanteer. Daarby het gemeeentebou as nuwe term bygekom. ' $n$ Begripsverwarring het ontstaan. Watter werksaamheid hoort by watter kommissie? In Die Sendingblad (Nov/Des 1985:381) berig die Vroueaksie van die Oos-Kaap: "ons werk vir sending, maar ons is baie deurmekaar". Sending het die betekenis van werk oor kultuurgrense heen gekry, terwyl evangelisasie basies gemik was op die "eie mense". Bosch se verduideliking in die nuwe handboek oor die sending (1979) het nog nie deurgewerk nie.

Reeds in 1978 (Die Sendingblad Des. 1978:44) vra dr Andries Botha van die Ned Geref Sendingkerk of die begrip "sending" nie eerder met "getuienis" vervang moet word nie, omdat sending die betekenis van werk gerig op die jongkerke gekry het. Die Ned Geref Sendingkerk sou bly vra vir 'n nuwe verstaan van sending. " $n$ Gesamentlike werkswinkel is in 1986 by die Universiteit van die Wes-Kaap gehou (Robinson \& Botha 1968) en het ' $n$ werksdefinisie van sending formuleer wat mettertyd opgeneem is in die Ned Geref Kerk se amptelike sendingreglement. Sending is God se sending (missio dei). Daaruit sou die kerk se sending (missio ecclesiae) vloei; dit sluit dimensies in van woord- 
getuienis (kerugma), liefdesdiens (diakonia), die vergestalting van die evangelie in die onderlinge verkeer van gelowiges (koinonia), die ywer vir ' $n$ regverdige samelewing (dikaioma) en aanbidding (leitourgia) alles in die Skrif saamgevat met die een term getuienis (marturia). Daar is verder ' $n$ onlosmaaklike band tussen die eenheid van kerk en die geloofwaardige bediening van die evangelie (Robinson 1988:62).

In 1977 is die Instituut vir Sendingwetenskaplike Navorsing (ISWEN), as werksaamheid van die ASSK en gekoppel aan die Teologiese Fakulteit van Pretoria, op die been gebring. Reusewerk is gedoen om die Ned Geref Kerk se sendinggeskiedenis op te teken (vgl Cronje 1982, Crafford 1981) en oor nuwe benaderings is besin. ' $n$ Indrukwekkende lys navorsingsprojekte en publikasies sou volg (Agenda Algemene Sinode 1990:319 en 1994:235). 'n Deurlopende projek in die tagtigerjare was die omvattende navorsing oor die onvoltooide sendingtaak. Al hoe meer bied die realiteit van die snelle verstedeliking (van veral swartmense) en industrialisasie nuwe sendinguitdagings. Oor die posisie van die trekarbeider, die regte van werkers, die swartmens in die stad en die kerk se roeping ten opsigte van die arbeidswêreld, is indringend besin. ' $\mathrm{n}$ Belangwekkende kongres oor Arbeid en Industrie is in 1984 gehou (Mens en Masjien). Die klem het vanaf die tuislande na die stede verskuif. Die navorsing oor die onvoltooide sendingtaak het uitgeloop op die groot sendingkongres in 1988 met die tema: "Die onvoltooide sendingtaak" Dié taak behels onder andere "n roeping tot voorbidding, die gemeenskap van versoendes, eenheid in verskeidenheid, dienslewering, rentmeesterskap en aanbidding. Die binnelandse sendingterrein bied nog reuse uitdagings aan die kerk (Kritzinger 1994).

In 1988 het ds Dawid Snyman uitgetree as voorsitter van die ASSK. Hy is opgevolg deur ds J v W du Plessis. In dieselfde jaar het ds P E S Smith sy emiritaat op sy 73 ste verjaarsdag aanvaar. Na die aftrede van dr J M Cronje is dr Andrew Hofmeyr in 1980 in sy plek as tweede ASSK sendingsekretaris beroep. Hy is in 1995 oorlede en in 1997 het ds Pieter de Wet ook afgetree. Sederdien is daar nie weer ' $n$ voltydse sekretaris aangestel nie. Die Sendingblad is in 1991 gestaak. Die Federale Raad het ophou vergader. Die einde van ' $n$ hele sendingera het met die aanvang van die negentigerjare aangebreek.

\section{GEMEENTE-INISIATIEWE IN 'N NUWE WÊRELD: DIE EEUWENTELING}

\subsection{Die nuwe Suid-Afrika breek aan}

Vroeg in 1990 kondig die "Nuwe Suid-Afrika" homself as "n groot verrassing aan, dit binne " $n$ nuwe wêreldorde na die val van die Berlynse muur. En in 1994 breek die jong demokrasie relatief vreedsaam deur. Dit 
was egter nie net die politiek, ekonomie en demografie wat dramaties verander het nie, ook die wêreld van mense se denke, waardes en behoeftes het, vir die tot dusver grootliks geïsoleerde Ned Geref Kerk, skynbaar oornag verander. Dawid Bosch (1991) skryf in sy magistrale werk, Transforming Mission, oor ' $\mathrm{n}$ nuwe paradigmaskuif: die era van post-modernisme is op hande. In hierdie totaal nuwe wêreld moes die Ned Geref Kerk haarself opnuut vind en haar identiteit en roeping uitklaar. Dit sou nie so oornag kon gebeur nie; "n tyd van onsekerheid en uiteenlopende benaderings sou volg, ook wat die kerk se sending betref.

Die tydperk word aanvanklik gekenmerk deur pogings om ontvlugting uit die onseker en bedreigende werklikheid waarin die kerk haarself skielik bevind het. Dikwels voer sinodes en gemeents finansieel ' $n$ oorlewingstryd; werksaamhede en poste moes verder afgeskaal word. Die lidmaattal krimp. Baie limate sou letterlik emigreer. Ander emigreer weer "na binne". " $n$ Wesenlike gevaar is dat die negentigerjare se groot klem op gemeentebou-modelle, vernuwingstrategië, charismatisering van die eredienste, profesionalisering van die leraar se bediening (opbreek in spesialiteite soos berading), spiritualiteitsvorming en sendingbetrokkenheid "daar ver", en verkieslik dan op korttermyn, by al die positiewe aspekte daarvan, tog tekens toon van hierdie ontvlugting en 'n na binne gekeerdheid.

\subsection{Gemeente-inisiatiewe en die fokus op wêreldsending}

Vanaf ' $n$ era waarin die sending gereglementeerd en georganiseerd vanuit sinodale sendingkantore bedryf is, het die pendulum nou deurgeswaai na gemeente-inisiatiewe. 'n Nuwe wêreld vir sendingbetrokkenheid het vir gemeentes oopgegaan. Van Niekerk (1997:414) skryf: "Oor die afgelope tien jaar het die inisiatief verskuif van sinodes na gemeentes, van opgeleide sendelinge na lidmate, van 'n plaaslike en Afrikafokus na 'n globale visie, van sentrale beheer na 'n wye verskeidenheid van benaderings, van eie kerklike strukture na deelname aan allerhande parakerklike organisasies"

Inderdaad is daar sprake van " $n$ verblydende nuwe geesdrif en sendingontwaking, maar die pogings is versplinterd in " $n$ wye verskeidenheid projekte en die lukrake ondersteuning van "sendelinge" oraloor. Sinergie en " $n$ teologies deurdagte benadering moet nog gevind word.

In die negentigerjare het die terrein van sendingbetrokkenheid inderdaad wêreldwyd verbreed.

- Die ondersteuning van die susterkerke op die tradisionele buitelandse sendingvelde is voortgesit. Die fokus het egter nou meestal verskuif na toerusting van inheemse leierskap, teologiese opleiding en korttermynuitreike deur gemeentes. 
- In veral Mosambiek het die deure vir betrokkenheid oopgegaan en is talle sendelinge werksaam. Hulle word deur sinodes, maar veral ook direk deur ' $\mathrm{n}$ aantal gemeentes uit verskillende sinodale streke ondersteun.

- Binnelands is daar hernieude pogings tot samewerking tussen Ned Geref gemeentes en sustergemeentes van die Ned Geref Kerkfamilie; daar is eger ook moedeloosheid oor die voortdurende tekort aan fondse, bedieningsprobleme en onderlinge spanning, byvoorbeeld die tussen die VGKSA en NGKA.

- Die binnelandse teologiese opleiding van die Ned Geref Kerk, VGKSA en NGKA word geïntegreerd aan die Teologiese Fakulteite van Stellenbosch, Pretoria en Bloemfontein aangebied en kan ' $n$ belangrike stap in die proses van eenwording en kontekstualisasie van die Ned Geref Kerk se benadering wees (Van Niekerk 2000). 'n Nuwe sendinghandboek begelei die sendingopleiding (Kritzenger et al, 1994).

- Daar is veral ' $\mathrm{n}$ ontploffing in betrokkenheid by wêreldsending. Die fokus is op die 10/40 venster, die voormalige Oos-blok lande en die mins-bereikte groepe. Dit is selfs nie eers moontlik om te probeer vasstel in watter lande van die wêreld daar oral sendelinge uit die Ned Geref Kerk werksaam is nie. Daar word met ' $n$ verskeidenheid sendingorganisasies saamgewerk. Makro-gemeentes en ' $n$ verskeidenheid parakerklike organisasies sou voortaan die pas aangee (Hendriks 1998). Dié strukture bied alternatiewe vir die kerkverband. Gemeentemobilisasie, netwerkvorming, "hubs", geloofsbelofte-offers, uitreike, die Jesus-Film, fondswerwing en gebedstrategië vir transformasie is gonswoorde in 'n nuwe sendingmetodiek. Daar word meestal aangesluit by Amerikaanse evangeliese en pragmatiese modelle. Daar was selfs ook tekens van 'n optimisme oor die naderende AD2000 (Meiring 1989). Die Amerikaanse Willow-Creek gemeente dien byvoorbeeld as belangrike sendingmodel (Getuies Augustus 1999).

- Die besinning oor die moontlikhede wat daar in Arbeidsbediening vir die kerk opgesluit lê (Agenda Algemene Sinode 1994:223), het daartoe gelei dat Arbeidsbediening met nuwe entoesiasme as ekumeniese werksaamheid, op veel breër terrein as die tradisionele Spoorwegbediening, aangepak is. Sending onder die Kommunisme het Biblia Hawesending geword.

- Die Algemene Sinode van 1998 het onder die indruk gekom van die dringendste terreine van nood in die huidige samelewing. Versoening (na die Waarheids en Versoeningskommissie wou die Ned Geref Kerk ook graag 'n eie bydrae maak), Armoede (en verwante 
probleme soos VIGS) en Morele-herstel (grootskaalse misdaad en geweld) het op die agenda gekom (die sg VAM-verslag voor die 1998 sinode). ' $\mathrm{n}$ Jaar van Hoop is vir 2001 uitgeroep en die kerk opnuut bewus gemaak van die roeping om 'n verskil in die gemeenskap te maak. Missionêre diakonaat het ingeskuif na die sentrum van die kerk se roeping. 'n Bewussyn groei dat die geloofwaardigheid van die kerk se getuienis afhang van die mate waarin dit slaag om met deernis, in dienskneggestalte, betrokke te raak by die nood van die wêreld, veral ook in Afrika-konteks. Die Kommissies vir Sending (ASSK) en Diens van Barmhartigheid (AKDB) werk hierin ten nouste saam en besin selfs daaroor of hul bedieningsterreine nog prinsipieel te skei is.

- In 1998 het Getuies as nuwe inligtingsblad vir die sending sy verskyning gemaak, vol berigte oor gemeente-inisiatiewe en gemeentebetrokkenheid by tradisionele sinodale velde, maar veral ook by allerlei opwindende, nuwe sendingterreine.

- Die CLF is kommersieel uitgebou en ondersteun ' $n$ verskeidenheid bedieninge.

\subsection{Sending as omvattende bediening}

In die negentigerjare het daar ' $n$ helderder definisie van sending uitkristaliseer. Sending as missio dei en 'n meer omvattende benadering vorm die basis daarvan.

"Sending is die heilshandeling van die drie-enige God, Vader, Seun en Heilige Gees met die wêreld waardeur Hy uit die ganse menslike geslag vir Hom 'n gemeente deur sy Woord en Gees vergader.

Deur die gemeente

- laat God sy Woord aan die gevalle wêreld verkondig;

- bring Hy die gemeenskap van heiliges uit alle nasies tot stand;

- laat Hy diens aan die wêreld in nood lewer;

- laat Hy sy opdrag om die skepping te bewaar en te bewerk sigbaar tot uitdrukking kom;

- en word sy reg aan die nasies verkondig. ${ }^{2}$

So laat God sy koninkryk kom tot by die voleinding van die wêreld.

2 Die laasgenoemde twee aspekte van die sendingdefinisie is foutiewelik weggelaat uit die Algemene Sendingreglement in Die Kerkorde van 1998. 
Daarom aanvaar die Ned Geref Kerk dit as die sin en bestemming van sy bestaan om deur God gebruik te word in sy handelinge met die mens en die wêreld.

Gelowiges uit elke taal en nasie wat sodoende vergader word, vorm saam met al die gelowiges " $n$ eenheid in ware geloof in Christus" (Die Kerkorde 1998:67).

Bepaalde begrippe is ook uitgeklaar: Sending is die bediening van die evangelie in al sy dimensies aan mense buite die kerk. Dit geskied langs die kanale van verkondiging, gemeenskap, diens en aanbidding. Daarteenoor het gemeentebediening te make met dieselfde omvattende bediening, maar dan aan gelowiges (gemeentelede) binne die kerk. Dit het ten doel om die gemeente op te bou en te begelei in sy getuienistaak teenoor mekaar, teenoor die afgedwaalde bondelinge en teenoor die wêreld. Evangelisasie is die speerpunt van beide sending en gemeente-bediening. Die element van evangelisasie, naamlik die punt waar mense van ongeloof tot ' $\mathrm{n}$ lewende geloof in Jesus Christus gelei word, maak die hart van sowel sending as gemeentebediening uit. Die Algemene Sinodale Sendingkommissie, wat vir ' $n$ tydperk die Algemene Kommissie vir Sending en Evangelisasie (AKSE) geheet het, het sy naam teruggekry (Agenda Algemene Sinode 1994:230).

\subsection{Saam op weg die $21^{\text {ste }}$ eeu in}

In 1986 is daar in Bellville " $n$ gesamentlike werksessie gehou oor die vraag: Wat is sending? By die geleentheid het verteenwoordigers uit die Ned Geref Kerkfamilie, wat normaalweg "broers buite hoorafstand" van mekaar is, die pyn van verdeeldheid teenoor mekaar bely en saamgestem dat "die eenheid van die kerk dié toetsteen van die sending is" (Notule AKGA 2001). Intussen het die ou Ned Geref Sendingkerk en die Ned Geref Kerk in Afrika in April 1994, pas voor die Nuwe Suid-Afrika amptelik arriveer het, in die Verenigende Gereformeerde Kerk in SuiderAfrika verenig. Dele van die Vrystaatse en Phororo-Sinodes van die NGKA het as sodanig bly voortbestaan, wat ' $n$ tragiese kerkskeuring en 'n langdurige spanning (selfs duur en uitgerekte hofsake) meegebring het. Vordering met die groter eenheidsproses is in die wiele gery. Sou die sending ' $\mathrm{n}$ uitweg kon vind? In die Wes-Kaap is die voortou geneem en het die Ned Geref Kerk, die VGKSA en die RCA in 1991 gesamentlike getuienisstrukture gevorm. In 1993 het die ASSK, ook met inisiatief uit Sendingkerk geledere, begin met ' $n$ lang en moeisame proses om die sendingstrukture van die binnelandse Ned Geref Kerkfamilie te verenig. In September 2001 is die eenheidsproses ' $n$ stap verder geneem toe die Algemene Kommissie vir Getuienisaksie (AKGA) gekonstitueer het met die onderneming om, wat die sending betref, voortaan saam op weg te gaan. Die NGKA staan egter nog buite. 
Die grootste uitdagings wat saam aangepak moet word is:

- om die eenheids- en versoeningsproses verder te help voer - eenheid in belydenis, maar veral ook eenheid in getuienis, bied die enigste egte basis vir strukturele eenwording.

- te besin oor die plek en aard van sending in die dialoog met ander godsdienste en in die post-moderne debat oor Christus as enigste Verlosser (Van Niekerk 1998, vgl ook Andries Louw in Getuies, Feb. 2002)

- 'n daadwerklike betrokkenheid by die nood van die wêreld (missionêre diakonaat), waarvan omvattende gemeenskapsbediening, die ekologie en die profeties, krities stryd om geregtigheid op mikro sowel as makro-vlak wesenlik deel is (Meiring 1989)

- 'n nuwe verstaan van missionêre gemeente-wees en 'n uitklaar van die rol wat die kerkverband in die sending behoort te speel.

- die voortgaande uitbou van 'n Skrifgehoorsame, gereformeerde sendingbenadering en -praktyk, in Afrika- en veral Suid-Afrikaanse konteks.

\section{Literatuurverwysings}

Argivale Bronne:

Notules Algemene Sinodale Sendingkommissie, 1965 -1998, Kerkargief, Pretoria.

Agendas en Handelinge Algemene Sinode Ned Geref Kerk, Kerkargief, Bloemfontein.

Notule Algemene Kommissie vir Getuienisaksie, Sendingkantoor, Bloemfontein.

Tydskrifte:

Die Sendingblad, Tydskrif van die Algemene Sinodale Sendingkommissie, 1965 -1991.

Getuies, Kwartaallikse bylaag tot Die Kerkbode, Inligtingsblad van die ASSK, 1999 2002.

\section{Boeke en Tydskrifartikels:}

Bavinck, J H 1954. Inleiding in de zendingwetenschap. Kampen: Kok.

Bosch, D J 1979. Heil vir die wêreld - die Christelike sending in teologiese perspektief. Pretoria: Ned Geref Kerk Boekhandel.

-, 1991, Transforming Mission, Paradigm Shifts in Theology of Mission. New York: Orbis.

Du Toit, H DA. Die kerstening van die bantoe, Pretoria: NG Kerkboekhandel.

Crafford, D 1966. Wêreldsending en wêrelddiakonaat. Universiteit van Pretoria: Ongepubliseerde DD verhandeling.

-, 1982. Aan God die dank 1. Pretoria: NGKB.

Cronje, J M 1981. Aan God die dank 2. Pretoria: NGKB. 
-, 1984. Vroue met Nardusparfuum. Pretoria: NG Kerkboekhandel.

Die Kerkorde 1998, Van die Nederduitse Gereformeerde Kerk. Wellington: Hugenote Uitgewers.

Erasmus, O C O en J J Botha (red) 1986. So stuur ek julle, 'n handleiding vir praktiese sendingwerk. Bloemfontein: Pro Christo Publikasies.

Gerdener, G B A 1951. Reguit koers gehou. Die wording, wese en werking van die Ned Geref Kerke se sendingbeleid, Kaapstad: NG Kerkuitgewers.

-, 1952. Die Blye Boodskap deur Drie Eeue in Suid-Afrika. Kaapstad: NG Kerkuitgewers.

-, 1958. Recent Developments in the South African Mission Field. Kaapstad: NG Kerkuitgewers.

Hendriks, J H 1998. Die kwynende invloed van sinodes in die Ned Geref Kerk. NGTT 39(4), 379-386.

Jonker, W D 1962. Die sendingbepalinge van die Ned Gereformeerde Kerk van Transvaal, Potchefstroom.

Kriel, C J 1961. Die Geskiedenis van die Nederduitse Gereformeerde Sendingkerk in Suid-Afrika 1881-1956. Wellington: Hugenote Uitgewers.

Kritzinger, J J 1994. Die onvoltooide sendingtaak in Suid Afrika. Pretoria: ISWEN.

Kritzinger, J J et al 1994. On Being Witnesses. Johannesburg: Orion.

Lombard, J A 1985. Ontwikkelinge in die sendingbeleid en -praktyk van die Nederduitse Gereformeerde Kerk gedurende die tydperk 1932 tot 1962. Universiteit van die Noorde: Ongepubliseerde DTh.

Meiring, P G J 1989. "Your will be done: Mission in Christ's way", Discerning God's will for mission in South Africa... tomorrow. Missionalia 18(1), 248-258.

Mens en Masjien, die Roeping van die Kerk in die industriële wêreld, 1984. Reëlingskomitee Kongres Kerk en Wêreld.

Robinson, P J 1986. Matteus 28:16-20 in die ontwikkelende sendingdenke van die Nederduitse Gereformeerde Kerk, in: Du Preez et al, (reds), Sendinggenade, Kaapstad: NG Sendinguitgewers, 86-101.

-, 1988. Die vraag na die definisie van die kerk se sending. Ongepubliseerde kongresbundel, Sendingjaar, UP.

Robinson P J en Botha, J G 1986. Wat is sending? 'n Werkswinkel vir die Familie van Ned Geref Kerke. UWK.

Smit, J H 1974. Die amp van die sendingleraar in die jongere kerke. Met besondere verwysing na die jongere kerke uit die sending van die Nederduitse Gereformeerde Kerk in Suid Afrika. US: Ongepubliseerde DTh.

Van der Merwe, W J 1967. Gesante om Christus wil. Kaapstad: NG Kerkuitgewers.

-, 1985. Die Pad Vorentoe - Die NG-familie se strewe na eenheid. Kaapstad: NG Kerkuitgewers.

Van der Watt, G 1990. G B A Gerdener, Koersaanwyser in die Nederduitse Gereformeerde Kerk se sending en ekumene. UV: Ongepubliseerde DTh. 
Van der Watt, P B 1987. Die Nederduitse Gereformeerde Kerk 1905 - 1975. Pretoria: NGKB.

Van Niekerk, A S 1997. Einde of begin vir die NG Sending? NGTT 38(4), 408-416.

-, 1998. Postmodernisme en Ned Geref Sending in die Nuwe Suid Afrika. NGTT 39(4), 367-378.

-, 2000. Die gesamentlike teologiese opleiding: 'n wonderwerk wat móét werk. NGTT 41(3\&4), 350-365. 